\title{
Um jogo sem final: a relação Lasier Martins e MST no contexto da recepção
}

\author{
Vilso Junior Santi \\ (vjrsanti@yahoo.com.br) \\ Jornalista graduado pela UCPel; Mestre em Comunicação Midiática pela UFSM e \\ Doutorando em Comunicação Social pela PUCRS.
}

\begin{abstract}
Resumo
O presente trabalho buscou avaliar e entender o processo de recepção (via produção de sentido) num grupo de agricultores assentados vinculados ao Movimento dos Trabalhadores Rurais SemTerra (MST). Com a finalidade de avaliar qualitativamente o resultado do embate, através de uma abordagem multiperspectívica - que envolveu os postulados de Douglas Kellner (2001), de Jesús Martín-Barbero (1997) e de Guillermo Orozco Gómez (2000) - o estudo promoveu o encontro das falas do comentarista Lasier Martins no Jornal do Almoço da RBS TV, acerca do MST e suas ações, com os enunciados dos próprios assentados, integrantes do Movimento, em torno dos posicionamentos do referido comentarista.
\end{abstract}

Palavras-chave: Estudos de Recepção. Telejornalismo de Opinião. MST.

\section{An endless game - the connection Lasier Martins X MST in the reception context}

\begin{abstract}
:
The present work aimed at evaluating and comprehending the reception process (by meaning production) in a group of agriculture workers from Movimento de Trabalhadores Rurais Sem-Terra (MST). In order to evaluate qualitatively the conflict results throughout a multi-perspective approach - which involved Douglas Kellner (2001), de Jesus Martín-Barbero (1997) and de Guillermo Orozco Gómez (2000) - the study promoted a connection between Lasier Martins' speech in Jornal do Almoço News TV programme from RBS TV about MST and its actions with the rural workers' ones concerning the commentator's positioning.
\end{abstract}

Keywords: Reception Studies. Opinative Telejournalism. MST.

\section{Introdução}

Através do encontro entre três das intervenções do comentarista Lasier Martins no Jornal do Almoço (JA) da Rede Brasil Sul de Televisão (RBS TV) - nas quais o Movimento dos Trabalhadores rurais Sem-Terra (MST) foi tematizado - e os agricultores do Movimento residentes no Assentamento Pitangueiras/Sem Fronteiras em Canguçu/RS, procurou-se avaliar 
qualitativamente o processo de recepção, conforme a produção de sentido que os agricultores fazem acerca das mensagens reportadas.

Utilizando-se do telejornalismo, em especial do telejornalismo de opinião, buscou-se, além de estabelecer uma ponte entre os contextos de produção e recepção, compreendê-los e analisá-los através de uma metodologia multiperspectívica. A opção metodológica do trabalho foi focada nos ensinamentos de Kellner (2001) acerca da pedagogia crítica da mídia, e nos postulados de MartínBarbero (1997) e de Orozco Gómez (2000) no que se refere às mediações e múltiplas mediações.

A delimitação do objeto de trabalho levou em consideração os anseios dos agricultores assentados em contrapor muito dos argumentos apresentados por Lasier Martins em suas intervenções no JA, mapeado através do pioneiro trabalho de Cruz (2006).

Para atender a esses propósitos, num primeiro momento, o esforço de pesquisa esteve relacionado à descrição e caracterização dos principais atores envolvidos no circuito comunicacional, ou seja, o MST e a RBS TV. Posteriormente, foram trabalhados os pressupostos teórico-metodológicos que deram suporte e embasamento às análises. Por último, promoveu-se o cruzamento e o encontro entre o referencial teórico-metodológico e os dados e informações levantados.

De posse dessas informações se propôs, analogicamente, uma forma de compreensão interpretativa para o fenômeno comunicacional, suas múltiplas mediações e desdobramentos compará-lo a um jogo de futebol. Finalmente, uma das versões plausíveis para o desfecho dos fatos, para esse jogo, está-se aqui apresentando.

\section{Caracterização do objeto}

Em tempos de avanço progressivo da cultura eletronicamente mediada, os telejornais passaram a ocupar um espaço cada vez mais central na vida das pessoas. Por atingir massificamente os mais diversos tipos de telespectadores, o telejornalismo pronuncia sua função social, em especial, frente aos menos favorecidos, para os quais na grande maioria dos casos, configura-se como a única fonte de informação diária sobre o quotidiano.

No Brasil, o surgimento da Rede Globo de Televisão, conjunturalmente beneficiada por uma série de fatores, inaugurou em 1965 um novo tempo no fazer jornalístico de TV. Derivam desse período o 'Jornal Nacional', principal telejornal brasileiro hoje, e o padrão Globo de comunicar. 
Segundo Lopes (2001, p.20), desde meados da década de 1970 “(...) é a Rede Globo quem escolhe e determina o que a nação deve assistir ou não".

Nesse sentido, a importância e influência da Rede Globo no atual cenário das telecomunicações no Brasil é enorme e pode ser evidenciada pelos seguintes dados: por intermédio de suas 113 afiliadas, entre geradoras e repetidoras, a Globo atinge 99,84\% dos 5043 municípios do país. Conforme Lima e Caparelli (2004), numa realidade onde a maior parte da mídia é controlada por elites políticas, igrejas e/ou grupos familiares, a Globo segue à frente das demais concorrentes reafirmando sua hegemonia.

Dentro da gigante Rede Globo, encontra-se atuando no Rio Grande do Sul e em Santa Catarina, sua filha mais pródiga, a RBS TV. O grupo de telecomunicações, pertencente à família Sirotsky, reproduz em nível local o caráter hegemônico de sua matriz, inclusive no que se refere ao gênero telejornalismo. Todo o poderio do 'Jornal Nacional', notadamente o telejornal mais visto pelos brasileiros, é correlato ao poderio do 'Jornal do Almoço', o telejornal mais assistido pelos gaúchos e catarinenses. O que muda apenas é o horário de apresentação dos programas.

Em sua produção, a RBS TV destina especial atenção ao gênero telejornalismo. A emissora se preocupa visivelmente em veicular informação de interesse regional, conforme suas bases de atuação, intercalando informações locais em sua programação estadual. Dentre seus principais programas de teleinformação estão o 'Bom Dia Rio Grande', o 'RBS Notícias' e o 'JA' (Jornal do Almoço) - um dos programas mais tradicionais da emissora (HINERASKY, 2004, p.33).

O JA foi ao ar pela primeira vez em 06 de março de 1972 pela então TV Gaúcha. Inédito no país, desde o início ele chamou a atenção e alterou a rotina dos telespectadores. Logo atraiu audiência e patrocinadores num espaço da grade de programação até então desvalorizado pelo baixo índice de 'Ibope'. A experiência pioneira da RBS TV se espalhou posteriormente para todo Brasil. Com a criação da Rede Regional de Notícias, que integrou todas as sucursais da RBS TV no Rio Grande do Sul, em 1979, o JA se consolidou como o telenoticiário de maior abrangência no estado e, em decorrência disso, como um lugar de produção e identificação regional.

Dentro do telejornalismo, o jornalismo de cunho opinativo é uma das marcas registradas do JA e da RBS TV. Com esse recurso o JA tenta equilibrar a equação impessoalidade versus posicionamento e passa a se articular e/ou transitar entre dois núcleos de interesse: a informação e a opinião. Segundo Bahia (1971, p.127), “o noticiário fica sendo a larga faixa impessoal de expressão 
dos fatos que interessam a todos de modo geral. O comentário editorial fica sendo a faixa opinativa, que aprecia em ângulos de maior responsabilidade os fatos que reclamam definição de posições”.

Na RBS TV e no JA, o telejornalismo opinativo especializado é personificado, dentre outros, pela figura do comentarista Lasier Martins. Lasier, que tem como base de atuação o Rio Grande do Sul, sistematicamente em seus comentários tematiza as coisas do lugar. Isso não significa, porém, que não teça considerações acerca de questões nacionais, principalmente de ordem política e econômica. Sucesso de público e crítica, Martins chama para si o rótulo de ícone opinativo da emissora para a qual trabalha.

Em outro ponto do circuito comunicacional, a partir de algumas diferenciações propostas por Gohn (1997, p.245), tem-se os movimentos sociais. Pode-se afirmar que: "um movimento social refere-se à ação dos homens na história. Esta ação envolve um fazer - por meio de um conjunto de procedimentos - e um pensar - por meio de um conjunto de idéias que motiva ou dá fundamento a ação".

Conforme Fausto Neto (1989, p.14), a expressão movimentos sociais "designa processos dinâmicos, instáveis, de organizações e ações distanciados em relação aos aparelhos do Estado". Assim, pode-se dizer que os movimentos sociais são formas de organização e mobilização que atuam como ligação entre os processos de reprodução social e a esfera política, constituindo-se como agentes e construtores entre os dois pólos. Esses movimentos trazem em sua essência o desejo de desempenhar um papel de transformadores da sociedade.

Cumprir o papel de agente transformador e mediador entre os campos sociais e político não é tarefa fácil. No Brasil rural esse personagem somente começa a ganhar corpo quando os trabalhadores do campo passam a ocupar um espaço de maior relevância na estrutura social. Isso se dá em meio a demorados, conturbados e por vezes até contraditórios fenômenos e/ou processos.

O pioneirismo na luta organizada pela terra no Brasil cabe ao Rio Grande do Sul através da constituição do MASTER (Movimento de Agricultores Sem-Terra). O MST (Movimento dos Trabalhares Rurais Sem-Terra), objeto desse estudo, vai surgir somente no início dos anos 1980. Na realidade, de acordo com Stédile e Görgen (1993, p.28), “(...) o Movimento dos Trabalhadores Rurais Sem-Terra não possui uma data específica que defina seu nascimento. A sua origem combina várias origens e vários locais e a sua história é composta pela soma de um conjunto de acontecimentos e fatores desenvolvidos a partir de 1978". 
Para Gohn (2000, p.106), o MST é atualmente o maior movimento social popular organizado do país e, talvez, o maior da América Latina. Sua base de atuação é o meio rural, junto aos trabalhadores rurais de diversas origens. "Muitos dos quais já foram pequenos proprietários, outros eram assalariados segundo várias modalidades de relação de trabalho e outros, ainda, são de origem urbana, viviam nas periferias das grandes cidades de diferentes regiões do Brasil”.

De acordo com Stédile e Görgen (1993 p.28), já na primeira metade da década de 1990, o contingente de trabalhadores rurais Sem-Terra ultrapassava 4,8 milhões. Atualmente, conforme estimativas 5,5 milhões de famílias rurais permanecem sem ter onde trabalhar no Brasil. Esse contingente, por si só, faz com que a luta do MST extrapole a simples regulamentação da reforma agrária. O Movimento hoje busca o exercício da democracia, da cidadania e da participação dos trabalhadores enquanto construtores de suas próprias histórias e da sociedade em que estão inseridos.

Nesse contexto, a mídia pode funcionar como um importante elemento de mediação entre os movimentos sociais como, por exemplo, o MST e o poder. Suas representações invariavelmente são contaminadas por interesses particulares e influenciadas por uma visão própria de mundo. Analisar tal cenário, de forma crítica, implica lançar mão de um aporte teórico-metodológico que possa considerar convenientemente essas questões.

\section{Delineamentos teórico-metodológicos}

Nesse múltiplo e complexo cenário, onde se configuram e atuam tanto os conglomerados de mídia como os movimentos sociais, estudar de forma crítica a comunicação passa a ser premissa básica para uma melhor compreensão do fenômeno comunicacional, da sua dimensão e de suas implicações. Na busca de atender essa condição, Rüdiger (2001) afirma que três correntes de pensamento foram, são e/ou podem ser utilizadas - a Economia Política; os Estudos Culturais; e os Estudos Culturais Críticos. Não obstante, é importante ressaltar que a teoria social crítica abriga escolas de pensamento como a de Frankfurt e também os Estudos Culturais Britânicos.

Para Johnson (1999, p.19), “os Estudos Culturais podem ser definidos como uma tradição intelectual e política; ou em suas relações com as disciplinas acadêmicas; ou em termos de paradigmas teóricos; ou, ainda, por seus objetos característicos de estudo". Sendo assim, pode-se afirmar que no centro de interesse dos Estudos Culturais estão as conexões entre a cultura, a história e a sociedade. 
Em solo brasileiro três momentos principais marcam a trajetória histórica dos Estudos Culturais enquanto linha de pesquisa. O primeiro deles foi a tradução para o português da obra "Cultura e Sociedade" de Raymond Willians em 1970. O segundo, o lançamento do livro "Dos Meios às Mediações" de Jesús Martín-Barbero e a difusão das idéias de outros autores como Néstor García Canclini. O terceiro momento demonstra claramente o parco conhecimento nacional para com a corrente dos Estudos Culturais (LOPES et al, 2002; CRUZ, 2006).

$\mathrm{Na}$ atualidade, conjugando algumas abordagens estrangeiras e nacionais, pode-se encontrar, porém, algumas relevantes contribuições. O norte-americano Douglas Kellner, por exemplo, situase hoje entre os principais teóricos que compõem a perspectiva dos Estudos Culturais Críticos com a qual se pretende trabalhar.

Kellner (2001) afirma categoricamente que não existem justificativas para o estudo em separado da cultura e da mídia. Ele, conforme Leite (2005), acredita que em tal processo as produções advindas dos meios de comunicação são sempre englobadas, de uma forma ou de outra, pela cultura. Sob essa realidade, uma nova forma de ver e criticar a mídia, é proposta por Kellner "a pedagogia crítica da mídia”. Nela são promovidas: a resistência à manipulação e, também, a "tonificação" do receptor em relação à cultura midiática dominante.

A introdução dos Estudos Culturais Críticos como paradigmas norteadores das análises em comunicação, conforme afirma Martín-Barbero (2003, p.280), deslocou o eixo dos debates “(...) dos meios para as mediações. Isto é, para as articulações entre práticas de comunicação e movimentos sociais, para as diferentes temporalidades e para a pluralidade de matrizes culturais".

Para Martín-Barbero (2003, p.274) “o campo daquilo que denominamos mediações é constituído pelos dispositivos através dos quais a hegemonia transforma por dentro o sentido do trabalho e da vida em comunidade". Assim sendo, complementa Cruz (2006, p.65), "além dos meios, existem as mediações, além das mediações tem-se a cultura".

A partir de então, nas análises do processo comunicativo, seja na produção ou na recepção, fazse importante atentar para as relações de poder envolvidas, sejam elas em nível micro - mais restritas, ligadas aos próprios ambientes de produção e recepção; ou em nível macro - referentes à estruturação geral da sociedade; sempre dentro de um contexto histórico (LOPES et al., 2002).

No que tange à recepção, em especial ao contexto de fala dos receptores, assume grande importância a verificação das condições em que a produção de sentido está sendo constituída (MARTÍN-BARBERO, 1997). Essas “posições de enunciação” (HALL, 1999, p.68) delineadas, são 
sempre individuais e se baseiam num contexto particular e, ao mesmo tempo, público. Ou seja, referem-se à "identidade cultural" de cada um, a qual consiste em um processo histórico de construção que interage todo o tempo com o campo social (CRUZ, 2006).

Dessa forma, partindo da concepção das mediações, consegue-se transpor os estudos da comunicação a outro patamar. Eles são transferidos do espaço restrito dos meios para o amplo espaço da cultura e mostram que as mediações têm uma relação direta com o processo de comunicação, uma vez que esse não se estabelece de maneira linear e simétrica. A partir de então, admite-se a existência de uma relação entre diferentes públicos mediatizada pelos contextos em que o processo de comunicação se estabelece. Nesse caso, uma leitura contextual da cultura da mídia, ao invés de simplesmente enxergar os fatos e/ou eventos reportados sob o prisma da dominação ideológica, deve tentar vê-los também como uma forma de reação, contra-resistência, a certa ordem dita hegemônica (CRUZ, 2006).

$\mathrm{O}$ receptor, portanto, em seu cotidiano e durante o movimento de sociabilidade, passa a estabelecer certo ritual, interagindo com os meios de comunicação e produzindo códigos culturais, seja através da "reprodução" - onde aceita tudo o que recebe, configurando-se como uma espécie de cúmplice do pensar hegemônico; da "negociação" - quando assimila apenas algumas partes daquilo que é exposto, descartando outras; ou da "resistência" - onde há construção de uma contraproposta informativa, gestada pela negação do sentido original veiculado pela mídia. (MARTÍN-BARBERO, 1997; OROZCO GÓMEZ, 1996).

É importante salientar ainda que o processo de recepção e sua duração não se restringem somente ao tempo de exposição do receptor frente ao meio e as mensagens por ele veiculadas. No caso do telejornalismo, a recepção não se inicia exclusivamente quando o aparelho de TV é ligado, tampouco acaba quando ele é desligado. Ela é um processo interacional complexo e contraditório. "Um processo que se entretém com a vida cotidiana e no qual intervêm distintos agentes e instituições sociais. Um processo, finalmente, que se desenvolve em distintos cenários" (OROZCO GÓMEZ, 1991, p.09).

Assim sendo, mais um passo se fez necessário dentro dos estudos comunicacionais e de recepção capitaneados pela teoria das mediações culturais. Esse novo passo diz respeito ao abarcamento do nível empírico nas análises. Tal fato é patrocinado por Orozco Gómez (1991), o qual desenvolveu o modelo das Múltiplas Mediações concebendo o processo de recepção como sendo um modelo nem linear e nem unívoco, que se dá em várias direções e que sofre a intervenção 
e o condicionamento de uma série de situações, dentre elas, do contexto cultural, político, histórico etc.

Para Orozco Gómez (1991), é tarefa das Múltiplas Mediações explorar a ritualidade, a tecnicidade e a sociabilidade no universo empírico. O autor (2000), no modelo que desenvolveu, aponta uma série de fontes de mediações que hipoteticamente são fundamentais para a compreensão do processo de recepção. Ele classificou essas fontes dentro de cinco categorias de mediações: individuais, institucionais, de referência, situacionais e massmidiáticas.

Na questão metodológica do modelo das Múltiplas Mediações, Orozco Gómez (2000) atenta para a necessidade de se eleger métodos de trabalho não ortodoxos e que façam uso combinado de formas tanto qualitativas quanto quantitativas em suas análises. Para ele, é fundamental a combinação de diferentes metodologias dentro de uma perspectiva histórica que permita sempre contextualizar a explicação dos fenômenos comunicacionais.

Segundo Orozco Gómez (2000, p.83), a investigação qualitativa "é um processo de indagação de um objeto, ao qual o investigador alcança através de interpretações sucessivas, com a ajuda de instrumentos e técnicas, que lhe permitem envolver-se com o objeto para interpretá-lo da forma mais integral possível".

Assim sendo, é importante frisar que, dentro das pesquisas de recepção, as mediações culturais se constituem apenas num modelo ou numa perspectiva de compreensão da relação entre cultura e meios de comunicação. Elas não são vias pavimentadas, fixas e prontas, disponíveis à explicação de um determinado fenômeno. Trata-se de um caminho novo, dinâmico e em construção, no qual o próprio objeto de estudo é quem revela quais as mediações que estão interferindo no processo e que irão compor o trajeto.

Dentro disso, a recepção deve ser entendida como um processo que pressupõe um contrato de comunicação. Esse contrato pode ser celebrado estando o sistema de mídia presente ou não. Assim, o estudo de recepção que envolve a relação meios (JA/RBS) versus audiência (agricultores assentados/MST), aqui proposto, é apenas uma das possibilidades.

\section{Da recepção e suas múltiplas mediações}

Aproveitando-se da afirmação de Orozco Gómes (2000) de que a Teoria das Múltiplas Mediações é um paradigma aberto e em construção, do clima de Copa do Mundo em 2006 que tomava conta do país e das próprias falas dos representantes do MST por ocasião dessa pesquisa de 
campo, resolveu-se ousar aqui, através de uma proposição análoga, um pouco inusitada para compreensão do fenômeno comunicacional dentro de uma abordagem qualitativa - compará-lo a um jogo de futebol.

Desse modo, a partida oficial que demarcou a intercessão efetiva entre o universo da produção, representado pelas intervenções de Lasier Martins no JA da RBS TV, e do mundo da recepção domínio dos integrantes do MST, moradores do Assentamento Sem Fronteiras, aconteceu dia 27/05/2006. Compuseram o time da recepção onze pessoas do referido assentamento, seis homens e cinco mulheres. Cerenita, José Vandemir - o Juca, Sidinei, Izolde e Fabiane, Adilson, Jussara, Zulmira, Jair; Jatir e Paulo que foram se alternado nas falas com o desenrolar do jogo e/ou dos debates.

Após as saudações, conversas preliminares, instalação dos equipamentos e acomodação dos presentes, abriram-se os trabalhos com uma auto-apresentação. Então, o material foi veiculado - três intervenções de Lasier Martins no JA da RBS TV que tematizavam o MST e suas ações. Ambas foram apresentadas em sequiência e depois reprisadas por solicitação dos presentes.

Com a bola em jogo - palavra - de imediato os agricultores assentados assumem uma posição defensiva. Seu sentimento de identificação para com o time do MST faz com que eles partam para uma nítida posição de blindagem para com a organização e para com eles próprios. Isso deixa claro um dos aspectos preponderantes do processo que marca a constituição identitária dos integrantes do MST - a resistência às informações veiculadas por Lasier Martins em seu espaço no JA da RBS TV.

Essa leitura resistente ou essa técnica de jogar na defesa deriva indubitavelmente da própria formação política dos agricultores, a qual é trabalhada dentro do Movimento de maneira ininterrupta. Toda ação dentro do MST, seja ela cotidiana ou de grandes proporções, envolve uma ação política. Implica compreensão, engajamento e participação de direito e de fato. Esse, aliás, é um dos insumos mais relevantes na sedimentação da matriz identitária dos membros do MST, elemento que interfere na compreensão geral que os assentados têm dos meios de comunicação. Os veículos são encarados como uma verdadeira arma repressora de quem o Movimento e seus membros têm que se defender. Segundo Paulo,

(...) a repressão aos pobres e aqueles que queriam ter o direito da terra, de trabalhar, do camponês, enfim, lá no século XVIII com o Conselheiro foi feita pelo canhão do Exército; depois no Contestado com o avião da Força Aérea; depois aqui no Rio Grande do Sul a repressão da polícia foi a muito laço. Eles viram que is so não dava mais. Então, eles começaram a usar a principal arma deles hoje, que não é mais o 
canhão, o avião e nem o cassetete do brigadiano e sim o meio de comunicação que é a pior arma que tem hoje.

Dessa forma, a necessidade de dar voz a seus argumentos, tidos como verdadeiros e reais, em contraponto às falas de Lasier é evidente. Dentro disso, os assentados apresentam dados, fazem contextualizações e dão testemunhos enriquecendo e explicando com detalhes seus posicionamentos e suas ações. Diferentemente, para eles, Lasier mostra desconhecimento das questões e não se preocupa em buscar os dados, em contextualizar as informações, o que the permitiria fazer uma leitura mais adequada das questões. Isso, segundo Orozco Gómez (1996), poderia ser chamado de "reducionismo informativo".

Assim sendo, por reconhecer o papel da mídia na atualidade, há uma forte preocupação dos agricultores com a possível interpretação do restante da sociedade, com a "visão que a sociedade tem do Movimento". Paulo diz que: "isso revolta a gente, tu ter que ouvir, e muitos que não têm esse contato assim, passam a acreditar na RBS e no Lasier." E complementa: "Daí eu vou mais longe ainda, o problema não somos nós. Nós do Movimento já temos uma consciência já lutamos e já conseguimos alguma coisa".

Diferente da defesa onde uns atacam e outros se defendem o meio campo no jogo da construção da identidade, via produção de significados no contexto da recepção, é por excelência o lugar da negociação, de trabalhar a bola. É nele, efetivamente, onde acontecem as trocas de passes e de símbolos, e onde ocorre o intercâmbio imediato de bens simbólicos e por consequiência a construção da identidade e da cultura. O meio campo é um lugar por excelência da criação. Todos os atores têm por objetivo construírem jogadas interpretativas e fazer prevalecer a sua forma de jogar. É onde ocorre a convergência de discursos, até mesmo os antagônicos que, segundo Cruz (2006), de tão divergentes podem se encontrar em suas extremidades.

A clara distinção de concepção, não só política e ideológica, mas também de compreensão de realidade fica também ilustrada. Não seria exagero afirmar que ambos os times vivem e vêem realidades diferentes. Cada um dentro de seu contexto, mesmo que troque significados, função exacerbada no meio campo do jogo da informação, não consegue de uma forma concreta compreender a realidade do outro. $\mathrm{O}$ espaço de intercâmbio, o espaço das mediações ou da cultura que forma identidades, existe e é importante. Mas, não é garantia de mudança de posição para um ou para outro time, dentro do jogo comunicativo de permuta de bens simbólicos. 
A partir dessas constatações, Juca passa a bola para o ataque, não sem antes admitir abertamente que o meio campo é um lugar que, embora não represente mudança imediata, principalmente das concepções de realidade, ao menos serve de palco para negociação de fato para troca e para o crescimento de ambos os agentes ou times envolvidos no processo comunicativo.

Eu não sei se os demais que estão aqui concordam com a minha avaliação. Mas, eu acho que serviu muito para o nosso crescimento, tanto para o MST quanto para os outros movimentos sociais. Serviu muito para nós, porque o que a gente tem apreendido com esses 'chiru' ai. Eles abrem a boca e tu já sabes que vem 'pau', pode se preparar que não tem outra coisa! Então, eu faço essa avaliação, que serviu muito para o crescimento dos movimentos sociais. A RBS com as atitudes dela e alguns jornalistas ditos 'bem conceituados' como é o Lasier Martins, como é o Mendelsky e esse reporterzinho, o Giovani Grizotti, fazendo essa palhaçada. Então acho que através da crítica divulgam e não dá para esperar outra coisa deles.

Desse modo, sentindo a necessidade de revisar seus procedimentos, na busca de apropriação do processo enunciativo, os integrantes do MST passam a usar em muitas situações os mesmos artifícios do seu opositor. Como num jogo de futebol, atacam para não serem atacados. Aos moldes de Lasier Martins quando aborda o Movimento, suas ações e seus integrantes, os agricultores lançam mão daquilo que chamamos de reprodução às avessas a fim de contrapor as formas discursivas utilizadas por aquele.

Essa reprodução, no que tange ao processo de formação identitária dentro do universo da cultura eletronicamente mediada e para o grupo em questão, não se dá pura e simplesmente em nível de conteúdo do discurso e ou da informação, do tipo copiar e colar. Dá-se, sim, em termos de estratégia discursiva ou forma de expressão. Nesse sentido, as mesmas acusações que são feitas por Lasier ao Movimento são reproduzidas pelo Movimento a Lasier. Enquanto este classifica o Movimento como um bando de vândalos, o Movimento, através de seus representantes, chama-o de bandido e indutor da miséria, conforme a intervenção de Paulo:

Acho que esses debates são muito bons de nós fazermos, e temos que continuar fazendo. Porque não dá para admitir que umas pessoas que têm o poder na mão, que nem o Lasier, quando fala ali de boca cheia que tem que prender. Eu acho que tem que prender quem induz a miséria e a pobreza e quem apóia a concentração de riqueza. O Lasier apóia, declaradamente, a concentração de riqueza, pois apóia o latifúndio!

Segundo os assentados, a RBS TV compartilha algumas características e valores com os latifundiários. Para eles, o mesmo coronelismo praticado no campo, através do exercício do poder, seja ele econômico ou coercitivo via violência, é reproduzido na RBS com outras ferramentas, através da informação e da angulagem que a emissora assume perante os fatos. Para Paulo, 
(...) é isso que justifica a ação da Aracruz! É esse os debates que nós tinha que poder ter o direito de fazer dentro do meio de comunicação. Mas o meio de comunicação é latifúndio também! O ar hoje é dos grandes! Nós só podemos falar assim como nós estamos falando aqui e em alguma radiozinha que nós criamos e que eles vêm e fecham. Porque nós não temos o direito de falar também?! Hoje o monopólio do ar também centralizou num grupo rico, que pensa em tudo em nosso País.

Conforme Paulo, uma das poucas formas que o Movimento dispõe de participar efetivamente do jogo, da disputa - e o MST claramente reivindica esse direito também no âmbito da comunicação - é através de suas manifestações e ocupações. Segundo o agricultor, é através delas que a organização consegue marcar alguns gols nos detentores do poder. Gols que, mesmo não servindo para virar o jogo, podem contribuir para chamar a atenção da torcida social para a equipe dos menos favorecidos.

Quando acontecem essas ações, e a gente tem que fazer porque é uma luta, e nós temos que lutar, é que nem um jogo de futebol. O pobre contra o rico! Então às vezes nós fizemos um gol neles. Na questão da Guerra, lá nós fizemos um gol neles, na questão da Aracruz foi um golaço! Porque mesmo depois, nós conseguimos abrir para a sociedade debater a questão do eucalipto, a questão do latifúndio.

\section{E o jogo não vai acabar?}

Ao se encarar a comunicação como um processo, onde a cultura se materializa como o principal agente mediador e também como fonte de mediação, automaticamente se está sugerindo a transposição dos estudos de comunicação para um novo patamar. Nesse novo degrau, alcançado dentro da busca do conhecimento nos estudos da área, estão as mediações que são efetivamente os elementos que vão outorgar sentido a essa comunicação enquanto processo, justificando desse modo sua própria existência.

Essa macro-cultura agente mediador, no entanto, é também mediada. Estudá-la e compreendêla implica, no balanço final, em estudar e compreender nossa própria organização social, suas disparidades e conflitos. E é nesse complexo cenário que a RBS TV e o MST, objetos desse estudo, desenvolveram e/ou desenvolvem suas relações.

Ao se admitir essa concepção, admite-se, por conseqüência, que tanto o processo de produção, quanto o processo de recepção, só podem ser analisados através de uma perspectiva relacional onde a própria vida social, seja de produtores, seja de receptores, junto com todas suas mediações impactantes devem ser apreendidas. 
Assim sendo, é através das mediações que, no contexto da recepção, mas dentro do cômputo geral, que o receptor interage com os meios produtores de comunicação desencadeando aquilo que se qualifica como processo comunicativo de fato. Nesse processo as diferentes mediações - a reprodução, a negociação e a resistência aos códigos, notícias e fatos veiculados - são as principais ferramentas utilizadas no jogo comunicativo e na produção de sentido às mensagens.

Desse modo, a posição de enunciação ocupada pelos agentes dentro do processo comunicativo, bem como os fatores componentes do cenário produtor/receptivo acabaram por deslocar as análises dos meios para as mediações onde, através de sua identidade, o receptor/produtor passou a construir significados culturais.

Isso implica analogamente a admitir e compreender a comunicação enquanto um processo dinâmico, de troca e de disputa, como um jogo de futebol, onde se tem equipes atuando num determinado cenário, em distintos pólos, e de acordo com a orientação de seus treinadores. Times que buscam defender seus interesses, suas posições e que almejam sempre a vitória ou a hegemonia. Estes, no decorrer do processo, acabam por se deparar com seus oponentes com os quais compartilham muito mais que seu objetivo e que seus interesses. Compartilham estratégias, artifícios e até mesmo argumentos.

Nesse cenário de disputas, acaba por ocorrer primeiro o contato, depois o conhecimento, e a troca - negociada ou não - de informações e/ou pontos de vista conforme os condicionantes implicados. Esses condicionantes ou mediações acabam por ser específicos e particulares para cada momento ou situação. Outra partida, em outro local, envolvendo outros times e elementos, provavelmente apresentará um resultado distinto.

Desse modo, tanto num jogo de futebol quanto no processo de comunicação, podem-se considerar dois times: um formado pelo conjunto de receptores o outro pelo coletivo dos produtores da informação. Estes, no entanto, podem alterar sua posição aleatoriamente dependendo do desdobramento e da sequência de eventos, não existem barreiras fixas ou condicionantes absolutos que os separe e/ou os fixe em nenhuma única posição.

No futebol todos os envolvidos no processo têm função previamente estabelecida: alguns defendem, outros trabalham a bola e outros ainda têm por função atacar. E, no time adversário, é a mesma coisa. Na comunicação, conforme perspectiva qualitativa das múltiplas mediações, essas funções não são estanques, principalmente no que se refere aos receptores. Todos, de fato, são responsáveis primeiro pela defesa com manutenção do time na disputa, depois pela negociação e 
neutralização do adversário e, por fim, pelo ataque na busca de fazer prevalecer o seu discurso marcar um gol.

Tudo isso ocorre dentro de um cenário, um campo, um estádio, um local capaz de abrigar essas inúmeras variáveis. Esse campo, para a comunicação, seria a própria cultura onde ocorre o intercâmbio dos bens simbólicos, onde se imprimem significados e onde são marcadas as posições identitárias.

Desse modo, devido à variedade de elementos envolvidos, característica inerente de um processo qualitativo de avaliação onde o empirismo se faz presente com grande peso relacional, para fins de sistematização, afirma-se que somente uma múltipla e complexa categoria de mediação poderia abarcar, compreender e explicar a relação estabelecida entre produtores - RBS TV - e receptores - MST - no campo e no jogo da comunicação. Essa categoria é a própria identidade tanto dos integrantes do Movimento quanto do próprio Lasier Martins.

É a identidade quem fundamentalmente vai determinar a forma de apreensão das notícias e informações e, no contexto da recepção, até dos comentários de Lasier reportados pela RBS. Podese dizer que é a posição identitária ocupada pelos representantes do MST a mediação que vai interferir de maneira singular no processo de comunicação. Ela é a principal forma de produção de sentido. Daí deriva o padrão de relacionamento, as formas de interação, os rituais de formação que conjuntamente vão emprestar sentido aos fatos e à própria realidade vivida, pois a identidade é formada pelas mediações ao mesmo tempo em que pode ser considerada uma categoria de mediação - fundamental, portanto, dentro do processo comunicativo e na produção de sentido.

Assim, pode-se considerar que a identidade do MST e de seus membros, ao mesmo tempo em que é formada ou composta pelas mediações segundo processos hîbridos principalmente de resistência, é um fator determinante no processo de compreensão, apreensão ou consumo de bens simbólicos, em especial aqueles vinculados às falas de Lasier Martins no JA da RBS TV.

A identidade, portanto, é ao mesmo tempo produto e produtora de sentido dentro de um campo de complexas interações, dentro de um jogo onde múltiplas mediações interferem no desenrolar das ações ou acontecimentos. Esse jogo, mesmo com o resultado sendo construído ao longo do tempo, não acaba, portanto, nos 90 minutos. Muito pelo contrário: implica desdobramentos que provavelmente ultrapassarão os limites da prorrogação e as conseqüentes cobranças de pênaltis. 


\section{Referências}

BAHIA, Juarez. Jornalismo, Informação e Comunicação. São Paulo: Livraria Martins, 1971.

CRUZ, Fábio Souza da. A Cultura da Mídia no Rio Grande do Sul: o caso MST e Jornal do Almoço. 2006. Tese (Doutorado em Comunicação Social) - Pontifícia Universidade do Rio Grande do Sul, Porto Alegre, 2006.

FAUSTO NETO, Antônio. Participação comunitária no Brasil: equívocos e desvios comunicacionais. In: MELO, José Marques de (org.). Comunicação na América Latina. Campinas: Papirus, 1989.

GARCÍA CANCLINI, Néstor. Consumidores e Cidadãos - conflitos multiculturais da globalização. Rio de Janeiro: UFRJ, 1999.

GOHN, Maria da Glória. Teorias dos Movimentos Sociais - paradigmas clássicos e contemporâneos. São Paulo: Loyola, 1997.

GOHN, Maria da Glória. Mídia, Terceiro Setor e MST: impactos sobre o futuro das cidades e do campo. Petrópolis: Vozes, 2000.

HALL, Stuart. A Identidade Cultural na Pós-Modemidade. Rio de Janeiro: DP\&A,1999.

HINERASKY, Daniela Aline. O Pampa Virou Cidade: um estudo sobre a identidade cultural nas produções de teledramaturgia da RBS TV. 2004. Dissertação (Mestrado em Comunicação e Informação) - Universidade Federal do Rio Grande do Sul, Porto Alegre, 2004.

JOHNSON, Richard. O que é, afinal, estudos culturais? In: SILVA, Tomaz Tadeu da (org.). O que é, afinal, Estudos Culturais? Belo Horizonte: Autêntica, 1999.

KELlNER, Douglas. A Cultura da Mídia. São Paulo: EDUSC, 2001.

LEITE, Sidney Ferreira. Estudos Culturais: o ponto da inércia e da resistência - Douglas Kellner e a leitura crítica do legado de Jean Baudrillard. Ecos Revista, Pelotas, v. 9, n. 1, p.107-132, jan/jun. 2005.

LIMA, Venício Artur de; CAPARELLI, Sérgio. Comunicação e Televisão: desafios da pósglobalização. São Paulo: Hacker, 2004.

LOPES, Genésio. O Superpoder - o Raios-X da Rede Globo: um império da ganância e da lucratividade. São Paulo: IBRASA, 2001.

LOPES, Maria Immacolata Vassalo de; BORELLI, Silvia Helena Simões; RESENDE, Vera da Rocha. Vivendo com a Telenovela: mediações, recepção, teleficcionalidade. São Paulo: Summus, 2002.

MARTÍN-BARBERO, Jesús. América Latina e os Anos Recentes: o estudo da recepção em comunicação social. In: SOUZA, Mauro Wilton de (org.). Sujeito, o Lado Oculto do Receptor. São Paulo: Brasiliense, 1995.

MARTÍN-BARBERO, Jesús. Dos Meios às Mediações: Comunicação, cultura e hegemonia. Rio de Janeiro: UFRJ, 1997.

MARTÍN-BARBERO, Jesús. Globalização comunicacional e transformação cultural. In: MORAES, Denis (org.). Por uma outra Comunicação - mídia, mundialização cultural e poder. Rio de Janeiro: Record, 2003. 
OROZCO GÓMEZ, Guillermo. Recepción Televisiva - tres aproximaciones y uma razón para su estudio. México: Universidad Iberoamericana, 1991.

OROZCO GÓMEZ, Guillermo (org.). Miradas Latinoamericanas a la Televisión. México: Iberoamericana, 1996.

OROZCO GÓMEZ, Guillermo. La Investigación em Comunicación desde la Pespectiva Cualitativa. Buenos Aires: Universidad Nacional de La Plata, 2000.

RÜDGER, Francisco. Comunicação e Teoria Crítica da Sociedade. Fundamentos da crítica cultural em Adorno. Porto Alegre: EDIPUCRS, 2001.

STÉDILE, João Pedro; GORGEN, Frei Sérgio. A Luta pela Terra no Brasil. São Paulo: Scritta: 1993. 